\title{
Urban Development and its Implications on Wetland Ecosystem Services in Ndop, Cameroon
}

\author{
Sunday Shende Kometa \\ Department of Geography, University of Bamenda \\ P.O. Box 39, Bambili, Cameroon \\ E-mail: shendek@hotmail.com \\ Jude Ndzifon Kimengsi (Corresponding author) \\ Department of Geography and Environmental Studies, Catholic University of Cameroon \\ P.O. Box 782, Bamenda, Cameroon \\ E-mail: jude.kimengsi@ catuc.org \\ Dereck M. Petiangma \\ Department of Geography and Planning, University of Bamenda \\ P.O. Box 39, Bambili, Cameroon \\ E-mail: aliciadereck@gmail.com
}

Received: August 26, 2017 Accepted: September 23, 2017

doi:10.5296/emsd.v7i1.12141 URL: https://doi.org/10.5296/emsd.v7i1.12141

\begin{abstract}
Wetlands provide a diversity of ecosystem services (provisioning, regulatory, supporting and cultural services) which are essential for the human society. This is particularly necessary in cases where large urban agglomerations exist. These services are increasingly coming under pressure as a result of rapid and uncontrolled urban development which remains phenomenal in the developing world. Cameroon can boast of a number of wetland environments particularly, the Waza Logone flood plain, the wetlands of the Bakassi Peninsula, Lake Barombi Mbo and the Ndop Plains. The wetland ecosystems of the Ndop Plains have increasingly come under pressure as a result of urban development which is mirrored in population growth, housing and other infrastructural developments. While significant
\end{abstract}


research works have been undertaken on aspects related to wetlands, agriculture and climate variability in the Ndop plains, there is insufficiency scientific information on the implications of urban development on wetland ecosystem services. Using questionnaire (where we systematically sample 140 households) and Landsat images which were complemented by field observations, relevant data were generated. With the aid of SPSS (version 21), the correlation between wetland ecosystem services and urban development at 0.05 level of significance was analysed. Our results reveal a significant negative relationship $(r=-0.551$ and -0.682) between urban development and the state of wetlands and their ecosystem services. This was further buttressed by geospatial data which revealed that the Ndop urban space increased from $3.7 \mathrm{~km}^{2}$ in 1999 to $11.7 \mathrm{~km}^{2}$ in 2017 . In this regard, we suggest that the coordination of the urban development process through land use planning and zoning is imperative in the face of unabated urban development. We equally suggest the need to implement wetland management policies in line with the Ramsar convention's paradigm on the "wise use" of wetlands.

Keywords: Wetlands, Ecosystem services, Urban development, Ndop, Cameroon

\section{Introduction}

Most UN-Habitat reports have re-echoed the fact that we live in an urban century - and the process of urban development continues unabated (UN-Habitat, 2009, 2016). Though the world is becoming increasingly urbanized, urban areas occupy just about $2 \%$ of the world's terrestrial surface. At the dawn of the $20^{\text {th }} \mathrm{C}$, only about $14 \%$ of humanity lived in cities. Today, about $50 \%$ of humanity are city dwellers. This implies that urban population has increased approximately fifteen times from 200million in 1900 to 2.9billion a hundred years later (United Nations, 2004). Rapid urban development in Africa which hosts some of the poorest cities in the world seriously threatens their resource base and ability to build adequate infrastructure and public services to meet the needs of their burgeoning population (UN-Habitat, 2016).

Although worldwide urban growth rates have increased, much faster rates are observed in some regions than others. Between 1995 and 2015, highest urban growth rates were registered in the least developed parts of the world with Africa being the most rapidly urbanizing. Africa's urban growth rate is estimated to be almost 11 times more rapid than growth rates in Europe. The driving forces of Africa's rapid urbanization include natural increase, rural-urban migration, spatial expansion of urban settlements through the annexation, and the reclassification of rural areas, among others. Considering the high poverty rates that characterize African cities, their rapid urban development signals a major challenge not only to their resource base, but also on the prospects to build and sustain adequate infrastructure and public services for their growing populations (UN-Habitat, 2016). Irrespective of the location, the growth of urban centres the world over, is ingrained in a culture of short-term economic benefit and often unbridled consumption and production practices that compromise the sustainability of the environment, including the wetland environment (UN-Habitat, 2016).

In order to cope with this astronomical growth in urban population, planned and unplanned 
developments have and are still being undertaken in all urban areas of the world (MDG Report, 2015). Urban population increase in most parts of the world is generally accompanied by greater increase in land consumption. A global sample conducted between 1990 and the year 2000 in 120 cities revealed that while the surface area occupied by built up areas grew on the average by $28 \%$ the population increased averagely only by $17 \%$ (UNEP, 2002). While by 2030 , the surface area covered by built up areas in the cities of developing countries is expected to triple, their population is rather expected to only double. Apart from being wasteful in terms of land and energy consumption, urban expansion has increased the emission of greenhouse gases and the alteration of ecological systems in many cities in the past two decades (UNEP, 2007). It was in this dimension that Paul and Meyer (2001) claimed that adjacent ecosystems are weakened and degraded as urban and semi urban land uses expand endlessly. Similarly, McKinney (2002) remarked that natural ecosystems are being destroyed and swallowed by the advancing frontiers of urban development and that the few surviving natural habitats around urban areas suffer from pollution, fragmentation and constant human interaction.

The Sustainable Development Goals capture the need to manage the process of urban development in Goal 11 (Make cities and human settlements inclusive, safe, resilient and sustainable).Specifically, Target 11.4 stresses on the need to strengthen efforts to protect and safeguard the world's cultural and natural heritage. It is important to note that such efforts can only be strengthened when specific links have been established between the urban development process and its effect on natural ecosystem services, particularly wetland environments. The Ramsar Convention (2007) defines wetlands as: areas of marsh, fen, peat land or water, whether natural or artificial, permanent or temporal with water that is static or flowing, fresh, brackish or salt, including areas of marine water the depth of which at low tide does not exceed six meters. According to Article 2.1 (2008) of the Ramsar Convention, "wetlands may incorporate riparian and coastal zones adjacent to the wetlands, and islands or bodies of marine water deeper than six meters at low tide lying within the wetlands".

The past decades have witnessed major transformations in human and ecological systems leading to a decline in a majority of ecosystem services (Millennium Ecosystem Assessment, 2005; Polasky, 2012). Significant transformations in this respect emanate from the process of urban development. Ecosystems are considered valuable because of the vast array of services (provisional, regulatory, supporting and cultural services) they provide to humans. Ecosystem services are the conditions and processes through which natural ecosystems and the species which make them up, sustain and fulfill human life (Daily, 1997). In the same light, the Millennium Ecosystem Assessment (2005) regards it as the benefits that people obtain from natural and semi natural ecosystems. Although they occupy only $6 \%$ of the earth surface, wetlands support approximately $20 \%$ of all living organisms, providing an important source of biodiversity (Zhoa \& Song, 2004). The U.S Environmental Protection Agency describes wetlands as "biological supermarkets" because the great quantities of food that they produce attract many animals. Thus, wetlands perform multiple tangible and intangible services to man and his environment.

In 2006, Cameroon ratified the Ramsar Convention that was adopted in 1971, amended in 
1982 and 1987. Cameroon's ratification of the convention is eloquent proof of her appreciation of the significance of these natural resources (Tazoacha, 2010). Cameroon has six Ramsar wetlands of International importance, namely, the Barombi Mbo Crater Lake, the Rio del Rey Estuary, River Ntem flood plain, River Sangha flood plain, Lake Chad region and the Waza -Logone Flood plain. Other important wetlands in Cameroon include the Mboh and Santchou plain, Ndop Flood plain, the Ndian Creeks, the Coast of Limbe, Tiko, Kribi, Douala, Edea, Lagdo, Songloulou and Maga. Urban development poses a great threat to these wetlands and their ecosystem services in Cameroon. The Wetlands of the Ndop Flood Plain in the North West region of Cameroon is a wetland of national importance. More than $70 \%$ of the inhabitants of this area depend directly and indirectly on the wetland for their livelihoods. The urban development process of Ndop is seemingly injurious to the health of the wetlands. This calls for a scientific investigation.

\section{Literature Review}

By virtue of their dynamism, urban areas are the hub of socio-economic development. They are capable of creating important economic opportunities and they have an interwoven network of productive units. Apart from offering jobs, services and shelter, they act as magnets for human population and generate much gross Domestic product (McInnes, 2010). The growth of these cities is caused by factors such as urban development, transformation and renewal (Fombe and Fogwe, 2001). These transformations largely impact on natural ecosystems including wetlands.

Wetlands perform a number of provisioning, regulatory, supporting and cultural functions which have been elaborated in many instances (Millennium Ecosystem Assessment, 2005; Ramsar Convention, 2013). The Ramsar Convention Secretariat (2013) contends that wetlands have a denitrification attribute in which impurities found in water are absorbed in a bid to improve their purity. Bassi et al.(2014), in a more quantitative approach found that the potential of wetlands to assimilate excess nutrients especially in the temperate areas is within the range of $1000-3000 \mathrm{~kg} \mathrm{~N} / \mathrm{ha} / \mathrm{year}$ and $60-100 \mathrm{Kg} \mathrm{P} / \mathrm{ha} / \mathrm{year}$. Generally regarded as environmental kidneys, wetlands sometimes contribute to water impurity especially in late winter and early spring in which they are characterized by the flushing out of vegetation (AECOM, 2011a; WWF and World Bank, 2003). The Millennium Ecosystem Assessment (2005) reported that wetlands hold exceptional values that are linked to the indigenous beliefs and cultures of some communities. Some wetlands have sacred, spiritual and universal ideologies, others contain appreciable archeological evidence and others are reserved for flora and fauna. Thus they offer important foundation on which other societal elements which may be social, economic and cultural could thrive (Ramsar Secretariat, 2013). This view is corroborated by Kharombi (2000) who cited the case of lake Fundudzi in the Limpopo Province of South Africa which is used by the paramount chief of the clan to perform religious practices. The lake has several spiritual myths which is orally shared from generation to generation. Some of the sites where sacrifices and blessings are sought from the gods in the four villages of Ndop Central Subdivision are very close to rivers and swamps. It is probable that these wetlands perform spiritual functions. 
In explaining the implications of urban growth on natural environments, Tiffany et al (2010) remarked that the hydrology of Contributing Drainage Areas(CDA) is affected by three main development processes notably the removal of native vegetation, creation of impervious surface and the creation of artificial drainage channels which facilitate the movement of surface runoff downstream and into wetlands. All these hinder ground water recharge which sustain wetlands since infiltration is discouraged. It has been documented that pressure on water resources such as ground water abstraction, surface and ground water pollution have impacts which extend beyond urban administrative boundaries (Hollis, 1990 and Kingsford, 2000). Schueler (2001) investigated this earlier and realized that compared to undeveloped meadow, total runoff volume from a one acre parking lot is about 16 times more. The thesis that direct and indirect impacts are inflicted on the environment by urbanization and that wetlands in particular suffer from negative effects has long been proven (Maltby, 1986). Pollution, habitat degradation and changes in hydrology are major human impacts on wetlands (Boyer and Polasky, 2004, Zhao and Song, 2004). The most recent tracking survey in the USA revealed two key findings on the nexus between urban development and wetlands. More than $60 \%$ of natural wetland fresh water loss was attributed to urban and rural development. Wetland loss due to development has been rising steadily with most of the losses occurring in small increments of less than 5 acre at a time. Thus the claim that the leading cause of wetland loss is development supports government attempt to protect wetlands from direct and indirect impacts of development (Tiffany et al., 2010). The haphazard manner in which houses are constructed in the town of Ndop cast doubts on government actions as far as wetland protection is concerned. The manners in which geographical systems operate in nature have been sidelined as far as urban development planning in Cameroon is concerned. Citing the case of Douala, Fogwe (2007) contend that the repercussions of stakeholders' negligence in the urban development process are now ubiquitously felt. Underground water pollution stemming from industrial growth is a typical example. Due to poor planning, some industries have been sited in the Ndogbong plateau which is a major watershed in Douala. Thus, instead of playing its role as a metropolitan watershed, it has become a metropolitan "wasteshed" (Fogwe, 2007).

At the center of the Ramsar philosophy is the concept of "wise use" of wetlands. Initially, it meant the sustainable utilization of wetlands for the benefits of humankind in consonance with the maintenance of the natural properties of ecosystems (Ramsar COP3, 1987). This definition was later updated to "the maintenance of their ecological character, achieved through the implementation of ecosystem approaches, within the context of sustainable development" (Ramsar Convention Secretariat, 2007). The Millennium Ecosystem Assessment framework equates "wise use" to the maintenance of the benefits and services of ecosystems to guarantee long term maintenance of biodiversity as well as human wellbeing and poverty alleviation. Wise use therefore has at its heart, the conservation and sustainable use of wetlands and their resources for the benefit of humankind. In this context, wise use centres on the need to coordinate urban development and preserve wetlands and regulation the extraction of wetland ecosystem services. The wise use concept applies to all wetlands ecosystems and not only wetlands of international importance. This is crucial because the choices people make plays an important role in enhancing human wellbeing and poverty 
alleviation which in turn depend on the maintenance of ecosystem benefits and services. According to McInnes (2010), the wise use concept is very relevant for urban wetlands especially those which support essential water and food requirements of urban areas.

\section{The Problem}

Urban areas are complex systems which are dynamic and not static. The pace of urban development in Africa remains unrivalled so far with Africa's urban growth rate. Such rapid development is associated with the depletion of ecosystems (including wetland ecosystems) and their services (UN-Habitat, 2016). Located in Sub Saharan Africa, Cameroon hosts numerous wetlands of national and international significance. Some of these include the Waza Logone flood plain, the wetlands of the Bakassi Peninsula, Lake Barombi Mbo and the Ndop Plains. The wetland ecosystems of the Ndop Plains have increasingly come under pressure as a result of urban development which is mirrored in population growth, housing and other infrastructural developments. While previous research efforts have directed towards dry season farming in the wetlands, climate variability and agriculture in the Ndop Plains (Lambi, 1999; Lambi, 2001, 2010; Kometa and Ndi, 2012), an important aspect which has not received significant research attention relates to the implications of urban development on wetland ecosystem services. In the regard, we seek to address the lacunae by analyzing the implications of urban development on wetland ecosystem services. Ndop which largely rests on a wetland environment has witnessed a significant growth in her urban space. This is mirrored in population increase, the expansion of settlements and other infrastructural developments, among others. For instance, between 1999 and 2017, the surface area for Ndop urban space increased from $3.7 \mathrm{~km}^{2}$ to $11.7 \mathrm{~km}^{2}$. This was logically accompanied by the encroachment and increasing dependence on wetland environments for their services. The urban development progression has seemingly been accompanied by retrogression in the size and value of wetland ecosystems and their services. An investigation into this impasse is important as it does not only scientifically edify stakeholders, but serves as a springboard for concrete actions to coordinate the urban development process while jealously preserving the remaining wetland ecosystems.

\section{Study Area and Methodology}

Ndop Central (Figure 1) is one of the three subdivisions that make up Ngoketunjia Division in the North West Region of Cameroon. Ndop, the headquarters of the division is about $40 \mathrm{~km}$ from the North West Regional Headquarter Bamenda. In absolute terms, Ngoketunjia division lies between latitudes $5^{\circ} 15^{\prime}$ and $6^{\circ} 10^{\prime} \mathrm{N}$ and $10^{\circ} 15^{\prime}$ and $10^{\circ} 40^{\prime} \mathrm{E}$ (Wirsiy, 2011). The population of Ndop Central was projected by to be 93706 in 2012 and using the same growth rate is projected at 107580 inhabitants in 2017. 


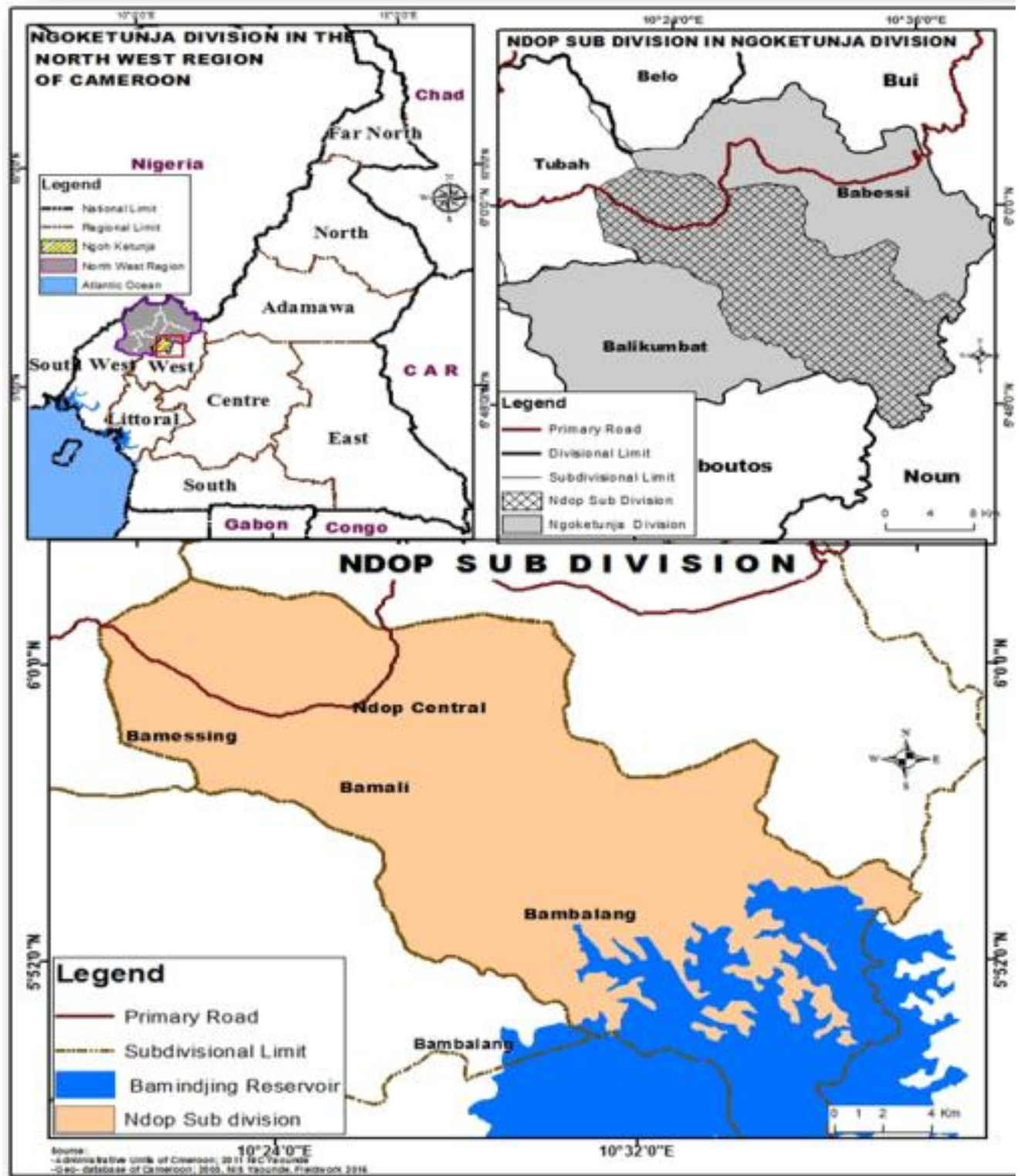

Figure 1. The location of Ndop Central in the North West Region of Cameroon

The target population consist of households at the fringes of wetlands in the town of Ndop and those who are directly involved in the management and extraction of wetland resources such as farmers, fishermen, hunters, sand dealers and wine tappers. The target population is estimated to be 2798 ( $2.6 \%$ of the total population). From the target population of 2798 , a $5 \%$ sample size representing 140 households were systematically sampled using a semi-structured questionnaire. The semi-structured questionnaire was designed to address specific aspects related to the trend of urban development, the spatial distribution of wetlands and wetland ecosystem services, and the implications of urban development on wetland ecosystem services. A systematic sampling of 140 households was conducted in which every $5^{\text {th }}$ household was targeted. This approach was further complemented by the design of an interview guide which was used to interview municipal and urban development stakeholders in Ndop. Furthermore, we employed the use of Landsat images which were complemented by 


\section{MInstitute Macrothink $_{\text {Intis }}$}

field observations to generate relevant data on the spatial distribution and extent of urban development and wetland service depletion. We then, with the aid of SPSS (version 21) analysed the correlation between wetland ecosystem services and urban development at 0.05 level of significance. This was done using the Pearson's Product Moment correlation in a bid to establish a relationship (r) between urban development and wetland ecosystem services. Geospatial analysis was equally conducted to reveal the changes in the urban space and wetland environments and services. The analysis therefore employed geo-spatial analysis (spatial extent of urban development and wetland degradation), descriptive statistics through the use of tables and percentages to show the land use proportions for the time periods considered, and the correlation analysis to establish the relationship (r) between urban development and wetland ecosystem services. In addition, the content analysis was employed to complement the analysis by expounding on the viewpoints of the interviewed persons.

\section{Results}

\subsection{Spatial Distribution of Wetlands in Ndop Central}

A wide variety of fresh water wetlands are found in Ndop Central (Figure 2). The map shows that most of the wetlands are generally found south of latitude $6^{\circ} \mathrm{N}$ and are predominantly in lowlands though a few patches are located in the vegetated mountainous area in the North West. The south eastern section is almost completely covered by the Bamendjin reservoir while the central portion consists of a high density of water bodies, swamps and rivers. Ndop covers a surface area of $448.5 \mathrm{~km}^{2}$ out of which $81.3 \mathrm{~km}^{2}$ consist wetlands (Table 1).

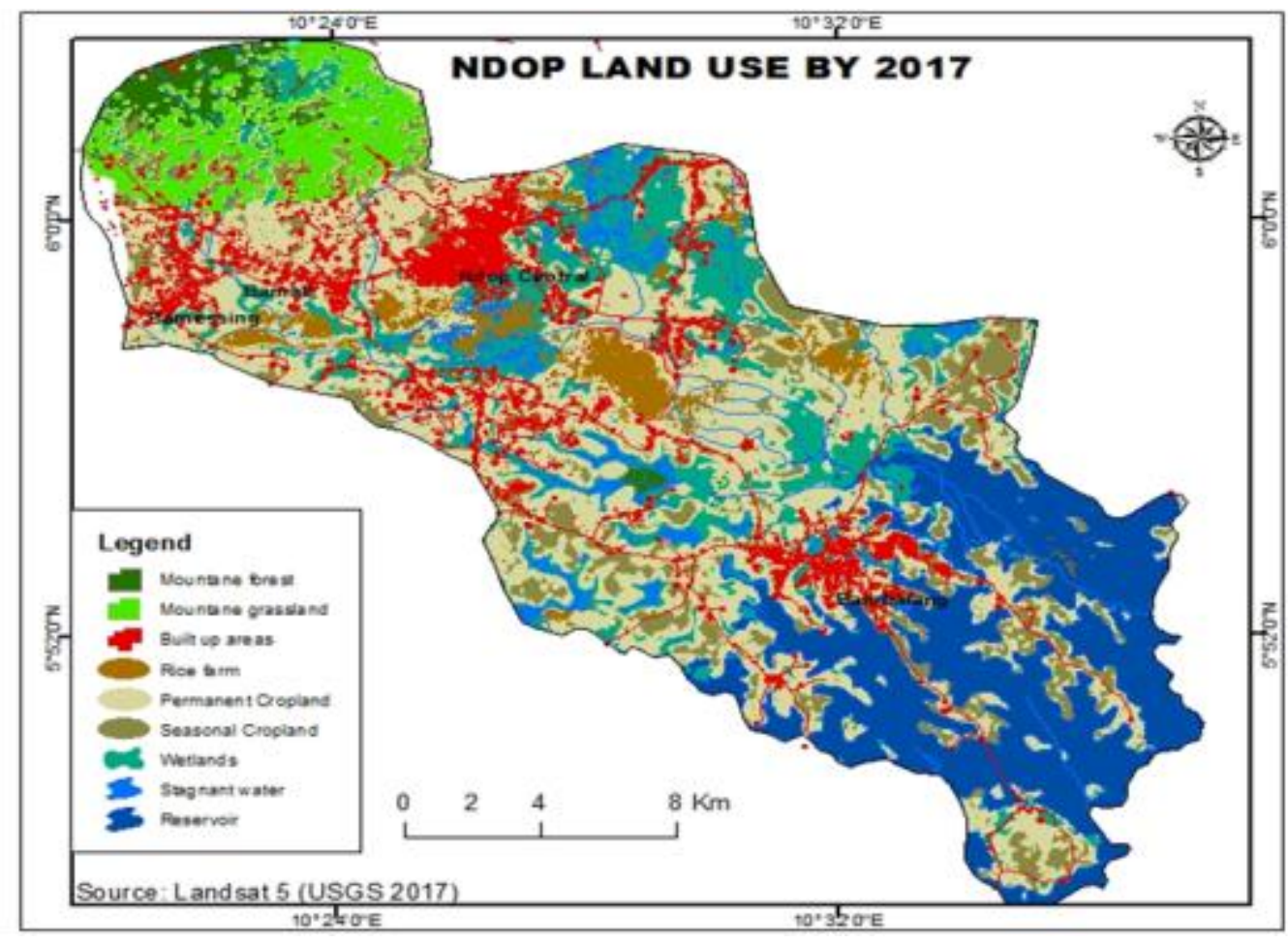

Figure 2. Distribution of wetlands in Ndop

Source: Landsat 5(USGS, 2017) 
Table 1. Distribution of wetlands by villages in Ndop central ${ }^{1}$

\begin{tabular}{|l|c|c|}
\hline \multicolumn{1}{|c|}{ Village } & Surface area in $\mathrm{Km}^{2}$ & Percentage $(\%)$ \\
\hline Bamali & 10.2 & 12.5 \\
\hline Bambalang & 36.3 & 44.6 \\
\hline Bamessing & 5.5 & 6.8 \\
\hline Bamunka & 29.3 & 36.0 \\
\hline Total & 81.3 & 99.9 \\
\hline
\end{tabular}

Source: Calculated from Landsat 5(USGS, 2017).

\subsection{Trend of Urban Development in Ndop}

The surface area covered by the urban space of Ndop has changed a lot between 1990 and 2017. Figure 3 shows the surface area of Ndop urban space in 1999 in relation to other land uses.

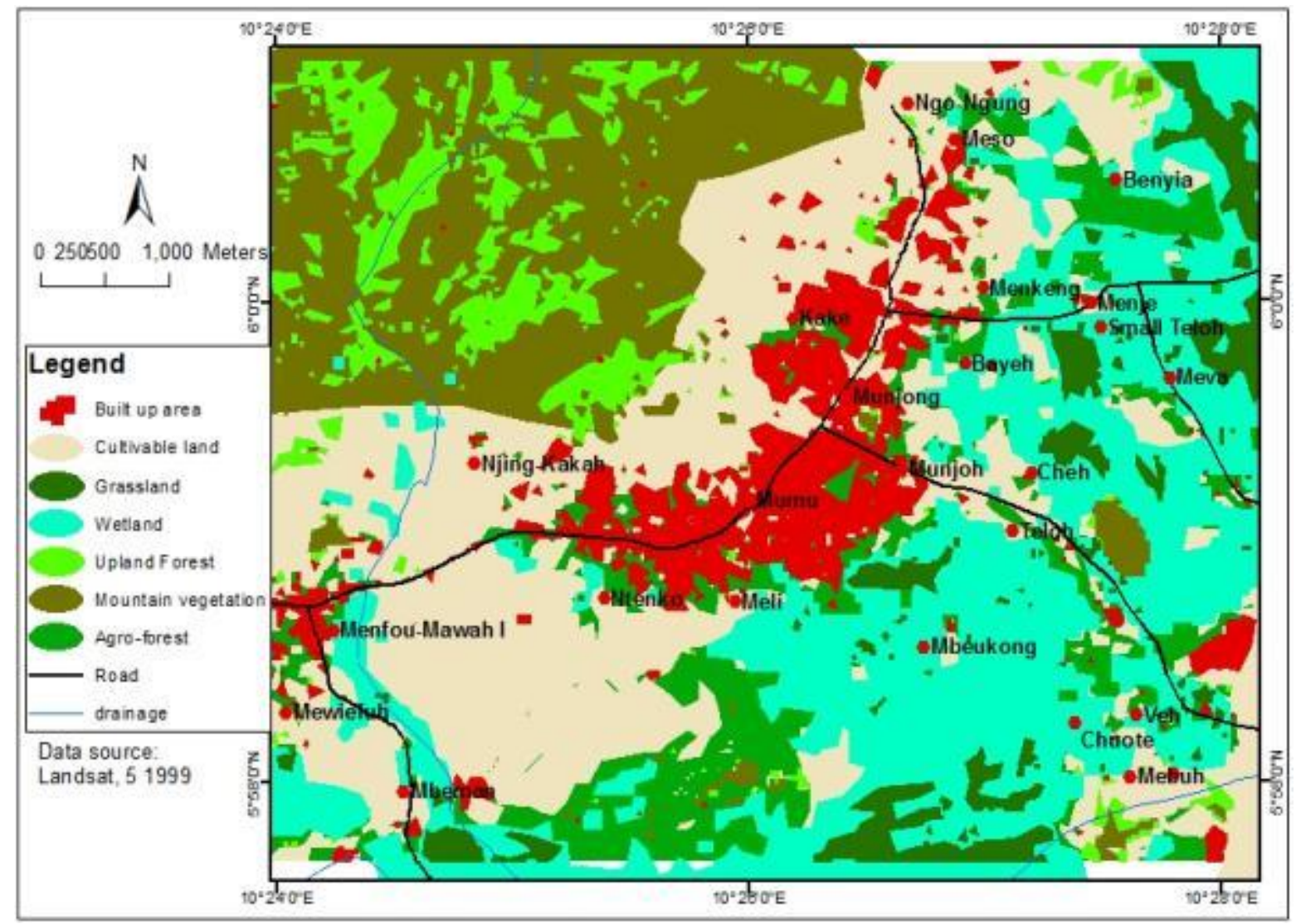

Figure 3. The Urban Space of Ndop in 1999

Source: Landsat 5, 1999.

\footnotetext{
${ }^{1}$ Surface area does not consider riparian areas, water bodies, man-made lacustrine systems and islands which are all considered by the Ramsar Convention as wetlands.Only the surface areas covered by swamps or marshes have been considered.
} 


\section{Mll Macrothink}

Environmental Management and Sustainable Development

ISSN 2164-7682 2018, Vol. 7, No. 1

According to Figure 3, the urban space of Ndop in 1999 was concentrated in Bamunka village which is the headquarters of Ndop Central Subdivision. Table 2 gives a summary of the surface area of the urban space of Ndop in 1999 alongside other land uses

Table 2. Surface Area of Ndop Urban Space and other Land uses

\begin{tabular}{|l|c|c|}
\hline \multicolumn{1}{|c|}{ Land uses } & Surface Area $\left(\mathrm{km}^{2}\right)$ & Percentage (\%) \\
\hline Built Up Area & 3.9 & 7.6 \\
\hline Cultivable land & 18.2 & 35.5 \\
\hline Grassland & 5.7 & 11.1 \\
\hline Wetlands & 11.5 & 22.4 \\
\hline Mountain Vegetation & 10 & 19.5 \\
\hline Agro forest & 2 & 3.9 \\
\hline Total & 51.3 & 100 \\
\hline
\end{tabular}

Source: Calculated from Landsat 5(USGS, 1999)

The figure and table shows that the surface area covered by the urban space of Ndop in 1999 was $3.9 \mathrm{~km}^{2}$ and represented only $7.6 \%$ of the surveyed surface area. Cultivable land covered $18.2 \mathrm{~km}^{2}$ which is $35.5 \%$ of the surface area. Grassland constitutes $5.7 \mathrm{~km}^{2}$ which is equivalent to $11.1 \%$ of the surface area while wetland occupies $11.5 \mathrm{~km}^{2}$ which correspond to $22.4 \%$ of the surface area. Mountain vegetation and agro forest cover $10 \mathrm{~km}^{2}$ and $2 \mathrm{~km}^{2}$ which correspond to $19.5 \%$ and 3.9 of the surveyed surface area respectively. Between 2000 and 2009 , the surface area covered by the built up area increased. Expansion was mainly along the main road covering areas of mountain forest within the urban space and towards the wetland areas in the south and south east as shown by Figure 4.

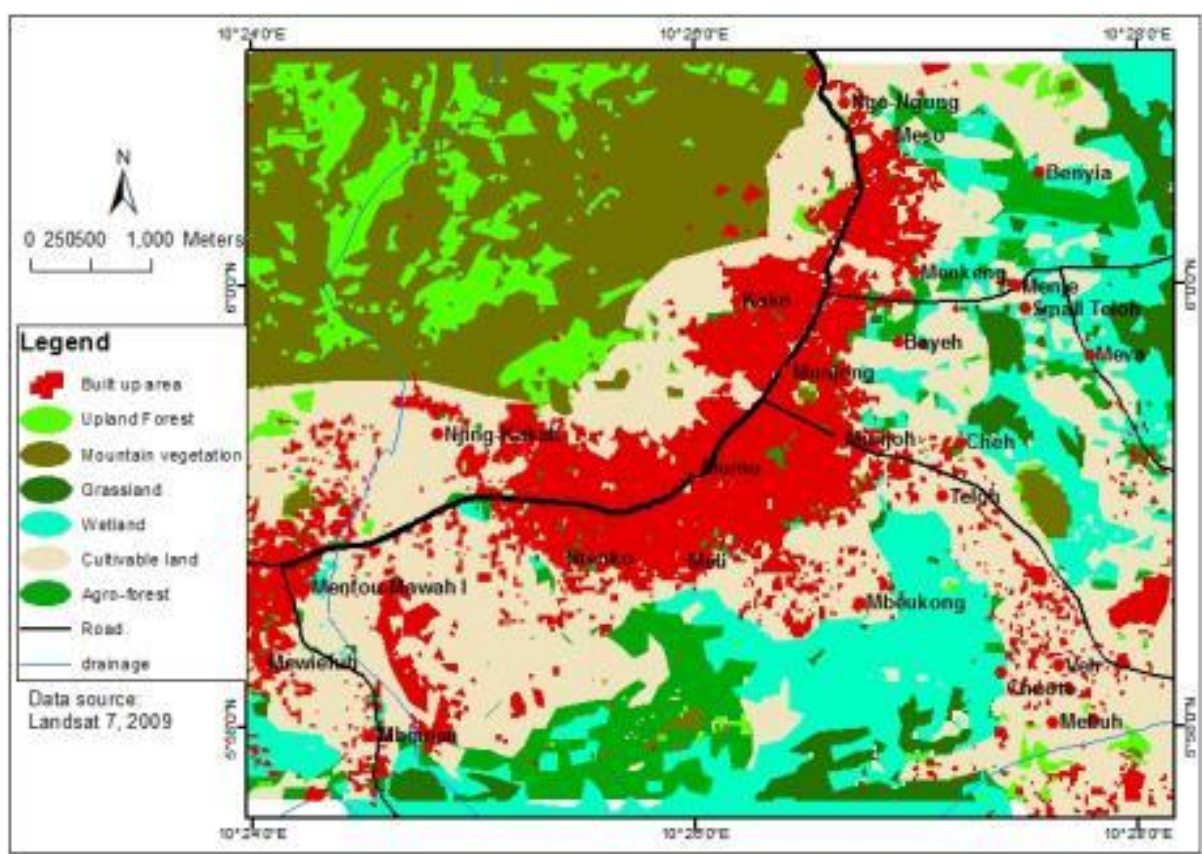

Figure 4. Built up area of Ndop Town in 2009

Source: Landsat7, 2009 


\section{Macrothink}

Environmental Management and Sustainable Development

ISSN 2164-7682 2018, Vol. 7, No. 1

Unlike in 1999 when the built up area was largely concentrated and characterized by large patches of agro forest and cultivated urban land, that of 2009 shows a marked decrease in the surface area of these rural activities within the urban space. Table 3 shows the surface area of the built up area of the town in 2009 and that of other land uses within the surveyed zone.

Table 3. land use and respective surface areas in 2009

\begin{tabular}{|l|c|c|}
\hline \multicolumn{1}{|c|}{ Land uses } & Surface Area $(\mathrm{km} 2)$ & Percentage $(\%)$ \\
\hline Urban Space & 7.3 & 14.2 \\
\hline Cultivable land & 17.7 & 34.5 \\
\hline Grassland & 5.3 & 10.3 \\
\hline Wetlands & 9.7 & 18.9 \\
\hline Mountain Vegetation & 9.6 & 18.7 \\
\hline Agro forest & 1.7 & 3.3 \\
\hline Total & 51.3 & 99.9 \\
\hline
\end{tabular}

Source: Calculated from Landsat 5(USGS, 2009)

According to the table, the surface area covered by the built up area of the town increased from $3.9 \mathrm{~km}^{2}$ in 1999 to $7.3 \mathrm{~km}^{2}$ in 2009 covering $14.2 \%$ of the total surface area of the surveyed zone as opposed to the $7.6 \%$ in 1999. Every other land use within the surveyed zone witnessed a reduction in size though at different rates. Cultivable land at the fringes of the urban space witnessed a decline in its surface area from $18.2 \mathrm{Km}^{2}$ to $17.7 \mathrm{~km}^{2}$. With increasing urban sprawl, the size of the urban space has increased again between 2010 and 2017. Figure 5 shows the surface area of the built up area in 2017.

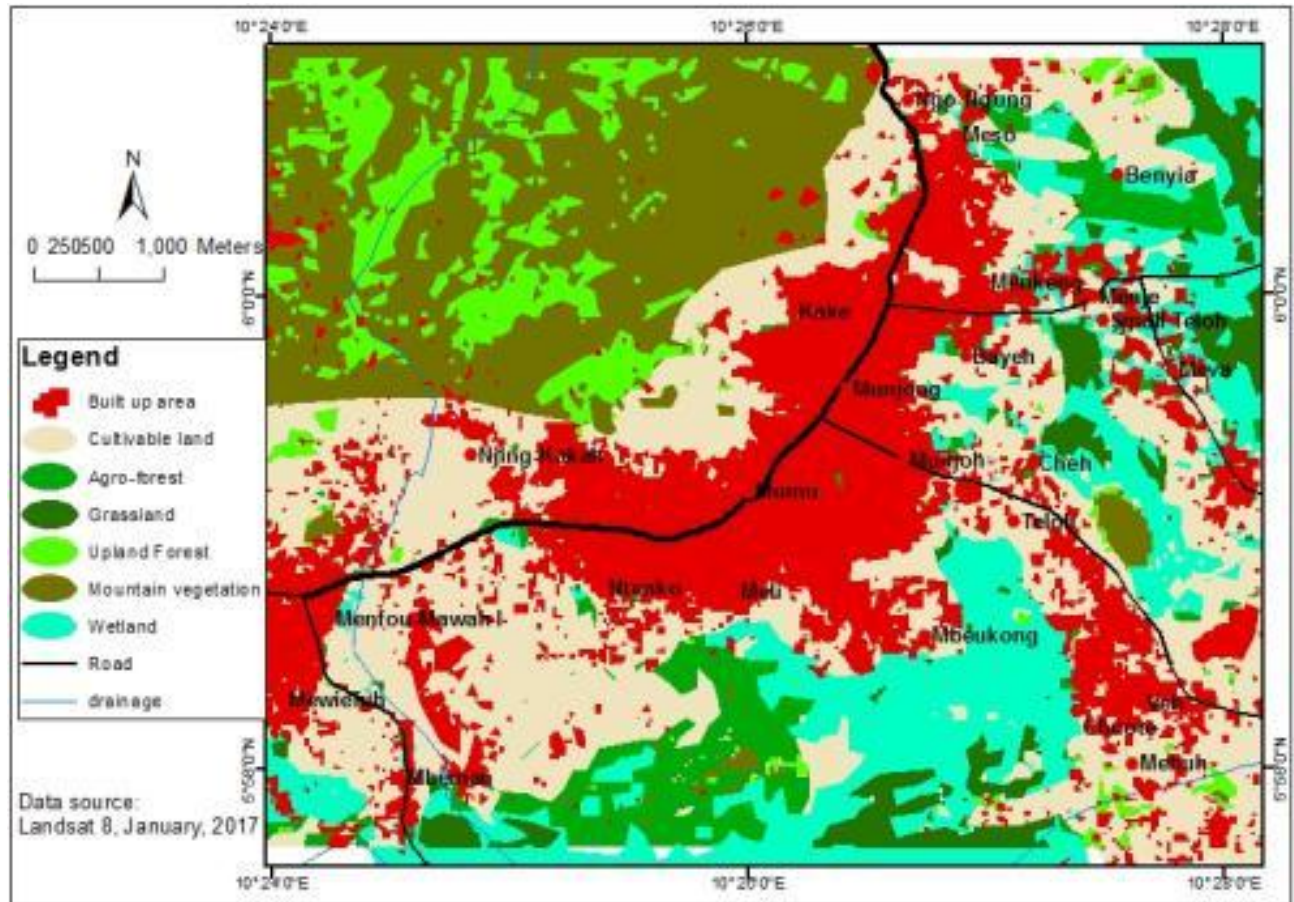

Figure 5. Built up Area of Ndop in 2017

Source: Landsat 8, 2017 


\section{Macrothink}

Environmental Management and Sustainable Development

ISSN 2164-7682

2018, Vol. 7, No. 1

Figure 5 shows further expansion of the built up area of the town in to cultivable land, wetlands and towards Bamali which in 1999 was largely rural. Table 4 shows the size of the surface area of Ndop urban space with that of surrounding land uses in 2017.

Table 4. land uses and surface areas in 2017

\begin{tabular}{|l|c|c|}
\hline \multicolumn{1}{|c|}{ Land uses } & Surface Area $\left(\mathrm{km}^{2}\right)$ & Percentage (\%) \\
\hline Urban Space & 11.6 & 22.6 \\
\hline Cultivable land & 16.8 & 32.7 \\
\hline Grassland & 4.9 & 9.6 \\
\hline Wetlands & 7.5 & 14.6 \\
\hline Mountain Vegetation & 9.4 & 18.3 \\
\hline Agro forest & 1.1 & 2.1 \\
\hline Total & 51.3 & 99.9 \\
\hline
\end{tabular}

Source: extracted from Landsat images 8 January 2017.

According to Table 4, the built up area covers $11.6 \mathrm{~km}^{2}$ which constitute $22.6 \%$ of the total surface area of the surveyed zone as opposed to 2009 when the surface area of the built up area was $7.3 \mathrm{~km}^{2}$ constituting $14.2 \%$. It is evident from the three different satellite images and related summaries presented in these tables that the surface area of the built up area of the town has increased from $3.9 \mathrm{~km}^{2}$ in 1999 to $7.1 \mathrm{Km}^{2}$ in 2009 and then to $11.7 \mathrm{~km}^{2}$ in 2017 . The rate of expansion from 1999 t0 2009 was $79.5 \%$ while from 2009 to 2017 it is $67.1 \%$. Table 5 shows the correlation coefficient matrix for urban development and wetland change.

Table 5. Correlation coefficient matrix for urban development and wetland change

\begin{tabular}{|c|c|c|c|}
\hline & & Urban development & Wetland Size \\
\hline \multirow{3}{*}{ Urban development } & Pearson Correlation & 1 & $-.551^{* *}$ \\
\hline & Sig. (2-tailed) & & .000 \\
\hline & $\mathrm{N}$ & 140 & 140 \\
\hline \multirow{3}{*}{ Wetland Size } & Pearson Correlation & $-.551^{* *}$ & 1 \\
\hline & Sig. (2-tailed) & .000 & \\
\hline & $\mathrm{N}$ & 140 & 140 \\
\hline
\end{tabular}

Source: SPSS version 21 output for hypothesis one test.

Using the Pearson's product moment correlation coefficient at 0.05 level of significance, a negative relationship $(\mathrm{r}=-0.551)$ was observed between urban development and wetland change, indicating that as the rate of urban development increases, the size of wetlands reduces. Again the p-value of 0.0 indicates that the relationship is statistically significant.

\subsection{Implications of Urban Development on Wetlands Ecosystem Services}

Analysis of the landsat satellite images showing the changing size of the built up area of the town of Ndop for 1999, 2009 and 2017 indicates that an inverse relationship exists between them. An increase of any magnitude in the size of the built up area is accompanied by a 
corresponding decrease in the total surface area covered by the other land uses (Table 6).

Table 6. Changes in size of Ndop Urban Space

\begin{tabular}{|l|l|l|l|c|c|}
\hline \multirow{2}{*}{ Landuse } & \multicolumn{3}{|l|}{ Surface area $(\mathrm{km} 2)$} & Net difference in \\
\cline { 2 - 5 } & $\begin{array}{l}1999 \\
(\mathrm{X})\end{array}$ & $\begin{array}{l}2009 \\
(\mathrm{Y})\end{array}$ & $\begin{array}{l}2017 \\
(\mathrm{Z})\end{array}$ & $\begin{array}{l}\text { surface area for 1999 \& } \\
\text { 2009 (Y - X) }\end{array}$ & $\begin{array}{c}\text { Net difference in surface } \\
\text { area for 2009 \& 2017 } \\
(\mathrm{Z}-\mathrm{Y})\end{array}$ \\
\hline Built up Area & 3.9 & 7.3 & 11.7 & 3.4 & 4.4 \\
\hline Cultivated Area & 18.2 & 17.7 & 16.8 & -0.5 & -0.9 \\
\hline Grassland & 5.7 & 5.3 & 4.8 & -0.4 & -0.5 \\
\hline Wetland & 11.5 & 9.7 & 7.5 & -1.8 & -2.2 \\
\hline Mountain Vegetation & 10 & 9.6 & 9.4 & -0.4 & -0.2 \\
\hline Agro forest & 2 & 1.7 & 1.1 & -0.3 & -0.6 \\
\hline
\end{tabular}

Source: Calculated from landsat Images of 1999, 2009 and 2017 of Ndop.

The net increase in the size of the built up area from 1999 to 2009 was $3.4 \mathrm{~km}^{2}$ and from 2009 to 2017 it was $4.4 \mathrm{~km}^{2}$. This was acompanied by corresponding net reductions in the combined surface areas of the other landuses of $-3.4 \mathrm{~km}^{2}$ and $-4.4 \mathrm{~km}^{2}$ respectively implying that urban expansion is uniquely responsible for the reductions. Thus, the loss of $1.8 \mathrm{~km}^{2}$ of urban and peri-urban wetlands between 1999 and 2009 and $2.2 \mathrm{~km}^{2}$ between 2009 and 2017 within the surveyed zone was caused by urban expansion.

As the surface area covered by these wetlands reduce progressively at the expense of urban expansion, the ecosystem services rendered by these wetlands are completely interrupted and destroyed. For instance,evidence from the three satellite images used for this analysis indicates that the wetland that separated the neigbourhood of Mbeukong in the south from the built up area of Ndop town in 1999 was exploited for farming by 2009 while the 2017 satellite image of the town indicates that the wetland has been completely converted into urban land. The Pearson product moment correlation coefficient at 0.05 level of significance showed a strong negative relationship $(\mathrm{r}=-0.682)$ between urban development and wetland ecosystem services in Ndop Central. The p-value of 0.0 indicates that the relationship is statistically significant. This implies that as the rate of urban development increases, the wetland ecosystem services produced by wetlands reduces in quantity.

\section{Conclusion and Recommendations}

Urban development in Ndop has been significant as in other parts of the developing world. This scenario has been injurious to the health of wetland ecosystems. Therefore, we concluded that at 0.05 level of significance a negative relationship $(\mathrm{r}=-0.551)$ exists between urban development and wetland change, indicating that as the rate of urban development increases, the size of wetlands reduces. In addition, a strong negative relationship $(r=-0.682)$ exists between urban development and wetland ecosystem services in Ndop implying that as the rate of urban development increases, the wetland ecosystem services produced by wetlands reduces in quantity. In this regard, we recommend that there should be an effective coordination of the urban development process through land use planning and zoning so as to control the rate of wetland encroachment by urban developmental activities. Furthermore, it 
is necessary for urban development and environmental conservation stakeholders of the area to tailor and implement wetland management policies in line with the wise use of wetlands paradigm of the Ramsar convention. The cultural, regulatory and supporting service role of the wetlands should be encouraged since they largely encourage the preservation of wetlands. In cases where the provisioning services are to be exploited, special zones should be allocated for such exploitation. The Ministry of Agriculture and Rural Development as well as the Ministry of Tourism, Environment and Nature Protection, Forestry and Wild Life should work in synergy to design a strategic plan which is aimed at implementing the "wise use" concept of the Ramsar Convention in the management of wetlands in Cameroon in general and in Ndop Central Subdivision in particular. Much scientific research on the economic valuation of the ecosystem services provided by the wetlands of Ndop should be encouraged and financed by the government so as to ascertain their potential economic value.

\section{References}

AECOM (2011a). 2008 NorthMet Mine/Forest Service Additional Parcel Summer Wildlife and Wetland Assessment - Final Report, Document NO. 05461-005-0400. https://www.leg.state.mn.us/docs/2015/other/150681/PFEISref.../AECOM\%202011a.pdf

Bassi, N., Kurmar, M. D., Sharma, A., \& Pardha-Saradhi, P. (2014). Status of wetlands in India: A review of extent, ecosystem benefits, threats and management strategies; Journal of Hydrology: Regional Studies, 2, 1-19. https://doi.org/10.1016/j.ejrh.2014.07.001

Boyer, T., \& Polasky, S. (2004). Valuing Urban Wetlands: A Review of non material valuation Studies. Wetlands, 24(4), 744-755.

https://doi.org/10.1672/0277-5212(2004)024[0744:VUWARO]2.0.CO;2

Daily, G. C. (1997). Introduction: What are ecosystem services? Pages 1-10, In: Daily, G.C. (Editor) Nature's Services: Societal Dependence on Natural Ecosystems. Island Press, Washington, DC: Washington, DC.

Fogwe, Z. N. (2007). The Transformation of an Urban Internal Watershed into a Wasteshed due to Industrial Zone Location Policy in Cameroon: The case of the Bassa Industrial Zone, Douala. Annals of the Faculty of Arts, Letters and Social Sciences, 1(6), 323-338.

Fombe, L. F., \& Fogwe, Z. N. (2001).Urban housing infrastructure: Renewal strategies and implications in the Bonaberi Suburban Area, Douala (Cameroon), in Lambi C. M., \& Eze B. E. (Eds.), Readings in Geography, Unique Printers, Bamenda.

Hollis, G. E. (1990). Environmental impacts of development on wetlands in arid and semi arid lands. Hydro. Sci., 35(4), 411-428. https://doi.org/10.1080/02626669009492443

Khorombi, M. (2000). Towards a sustainable land-use plan for the lake Fundudzi catchment area, MInstAgrar dissertation, University of Pretoria, Pretoria. https://repository. up.ac.za/ handle /2263/30431.

Kingsford, R. T. (2000). Ecological impacts of dams, water diversions and river management on floodplain wetlands in Australia. Austral Ecology, 25(2), 109-127. 
https://doi.org/10.1046/j.1442-9993.2000.01036.x

Maltby, E. (1986). Waterlogged wealth: Why waste the world's wet places. Earthscan, London, UK.

McInnes, R. (2010). Urban development, biodiversity and wetland management. Expert Workshop Report, Bioscan (UK) Ltd Oxford, UK. mirror.unhabitat.org /downloads /docs /ExpertWorkshopWetlands.pdf

McKinney, M. L. (2002). Urbanization, biodiversity, and conservation. Bioscience, 52(10), 883-890. https://doi.org/10.1641/0006-3568(2002)052[0883:UBAC]2.0.CO;2

Millennium Development Goal Report (2015)

Millennium Ecosystem Assessment (2005). Ecosystems and human well - being: wetlands and water synthesis: a report of the Millennium Ecosystem Assessment. World Resources Institute, Washington DC, USA. 68p.

Ndop Communal Development Plan (2012)

Ndop Council Baseline Data (2012)

Paul, J. M., \& Meyer, J. L. (2001). Streams in the urban landscape. Annual Review of Ecology and Systematics, 32, 333-365. https://doi.org/10.1146/annurev.ecolsys.32.081501.114040

Polasky, S. (2012). Valuing nature: economics, ecosystem services, and decision making. In Measuring nature's balance sheet of 2011 Ecosystem Services Seminar Series. Edited by Coastal Quest and Gordon and Betty Moore Foundation, 70-83, Palo Alto: Gordon and Betty Moore Foundation, 2012.

Ramsar Convention Secretariat (2007). Wise use of wetlands: A conceptual framework for the wise use of wetlands. Ramsar handbooks for the wise use of wetlands, 3rd edition, volume 1. Ramsar Convention Secretariat, Gland, Switzerland.

Ramsar Convention Secretariat (2010). Wise use of wetlands: Concepts and approaches for the wise use of wetlands. Ramsar handbooks for the wise use of wetlands, 4th edition, vol. 1. Ramsar Convention Secretariat, Gland, Switzerland.

Ramsar Convention Secretariat (2013). The Ramsar Convention Manual: a guide to the Convention on Wetlands (Ramsar, Iran, 1971), 6thed Ramsar Convention Secretariat, Gland, Switzerland (Ramsar Convention Secretariat 2013).

Schueler, T. (2001a). The Importance of Imperviousness. In T. Schueler and H. Holland (eds). The Practice of Watershed Protection. Center for Watershed Protection. Ellicott City, MD

Tazoacha, F. (2010). Managing wetland ecosystems to guarantee water security in Cameroon, http://www.monitor.upeace.org/archives.cfm?id_article=716, last updated 05/04/2010/

Tiffany, W., Tomlinson, J., Schueler, T., Cappiella, K., Kitchell, A., \& Hirschman, D. (2010). Direct and indirect impacts of urbanization on wetland quality. Center for Watershed Protection 8390 Main Street, 2nd Floor Ellicott City, MD 21043 
UNEP (2002). Global Environmental Outlook 3: Past, present and future perspectives. Earthscan, London

UNEP (2007). Global Environmental Outlook: Environment for development. Progress Press Ltd, Valleta, Malta, www.unep.org/geo/geo4/report/GEO-4_Report. accessed 3 April 2016.

UN-Habitat (2009). Global Report on Human Settlements 2009: Planning Sustainable Cities, Earthscan, London and Sterling, VA

UN-Habitat (2016). Urbanization and development: Emerging futures. World Cities Report. United Nations Human Settlements Programme, 2016

United Nations (2004). World Urbanization Prospects: The 2003 Revision. New York: United Nations Population Division, Department of Economic and Social Affairs.

Wirsiy, F. Y. (2011). Annual report of activities carried out by the Divisional Delegation of Agriculture and Rural Development, Ngoketunjia. Ministry of Agriculture and Rural Development, Cameroon. pp.1-2.

WWF and the World Bank (2003). Running pure - The importance of forest protected areas to drinking water. WWF and The World Bank.

Zhao, O. G., \& Song, J. (2004). Wetland utilisation and protection in China. In Wong M.H. ed. (2004). Developments in ecosystems, volume 1: Wetlands ecosystems in Asia: Function and management, 27-34.

\section{Copyright Disclaimer}

Copyright for this article is retained by the author(s), with first publication rights granted to the journal.

This is an open-access article distributed under the terms and conditions of the Creative Commons Attribution license (http://creativecommons.org/licenses/by/3.0/). 